\title{
Ethical Leadership
}

Katarina Katja Mihelič, Msc, University of Ljubljana, Slovenia Bogdan Lipičnik, Phd, University of Ljubljana, Slovenia

Metka Tekavčič, Phd, University of Ljubljana, Slovenia

\begin{abstract}
The paper examines the construct of ethical leadership. Ethical leaders think about long-term consequences, drawbacks and benefits of the decisions they make in the organization. They are humble, concerned for the greater good, strive for fairness, take responsibility and show respect for each individual. Ethical leaders set high ethical standards and act in accordance with them. They influence ethical values of the organization through their behaviour. Leaders serve as role models for their followers and show them the behavioural boundaries set within an organization. They are perceived as honest, trustworthy, courageous and demonstrating integrity. The more the leader "walks the talk", by translating internalized values into action, the higher level of trust and respect he generates from followers.
\end{abstract}

Keywords: ethical leader, character, leader-follower relations, ethical culture

\section{INTRODUCTION}

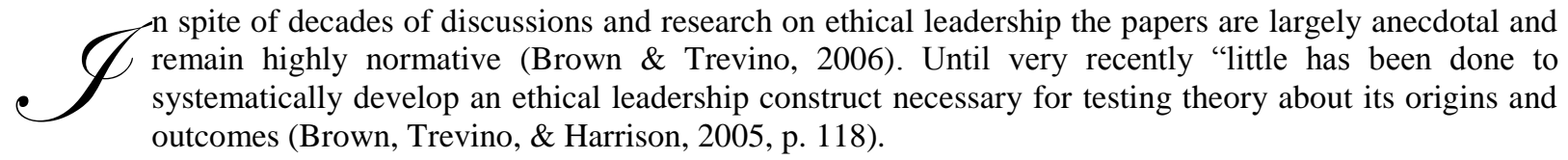

It is particularly in times of corporate scandals and moral lapses that the broader public and interest groups in a corporation ask themselves the fundamental question, namely, who are corporate managers and are they ethical. It is only in the recent years that managers and researchers have turned their attention to ethics management (L. K. Trevino \& Brown, 2005). The concern for "ethical consciousness" comes at the time when the concept of leadership legitimacy is questioned and when the public's trust in corporate governance is extremely low (Fulmer, 2005). Leaders ought to be a crucial source of ethical guidance for employees and should at the same time be responsible for moral development in an organization. People might think that ethics is something intimate, a confidential matter that an individual and his conscience share. How we behave, how we reach goals (as long as they are legal and legitimate), might not seem important, and some might even say that ethics has nothing to do with management. The truth s however just the opposite, ethics has a lot if not everything to do with management/leadership. And managers' behaviour is disseminated throughout the corporations and their behavioural standards are the crucial part of corporate climate, and when stabilized, culture.

The purpose of this paper is to shed light on the construct of ethical leadership by reviewing the relevant literature. The aims of the paper include providing definitions for the construct of ethical leadership and describing an ethical leader's personality. Furthermore, we evaluate the major determinants of leader's ethical behavior in an organization. The research questions of the paper include: what are crucial personality characteristics of an ethical leader and what is his typical behavior? What is the leader's role in fostering followers' ethical behavior and how do followers perceive an ethical leader? We also provide the results from scarce empirical studies about ethical leaders and the followers' perception of ethical dimension in leaders. The structure of the paper reflects the purpose and follows the research questions. 


\section{ETHICAL LEADERSHIP: DEFINING THE CONSTRUCT}

Ethical leaders speak to us about our identity, what we are and what we can become, how we live and how we could live better. (Freeman \& Stewart, 2006)

Ethics is a philosophical term originating from Greek word "ethos" meaning custom or character. It is concerned with describing and prescribing moral requirements and behaviors, which suggests that there are acceptable and unacceptable ways of behaving that serve as a function of philosophical principles (Minkes, Small, \& Chatterjee, 1999). Ethical behavior is defined as behavior which is morally accepted as "good" and "right" as opposed to "bad" or "wrong" in a given situation (Sims, 1992). Ethics is the code of values and moral principles that guides individual or group behaviour with respect to what is right or wrong. Ethical behaviour is both legally and morally acceptable to the larger community (L. K. Trevino, 1986). Ethical dilemmas though, are present in uncertain situations, in which different interests, values, beliefs pertaining to multiple stakeholders are in conflict.

Narrowly, in an organizational context, ethics can be viewed as a frank conversation about those values and issues most important to stakeholders and to business. In a way, it is a continuous discovery and reaffirmation and evaluation of own values and principles (Freeman \& Stewart, 2006). Ethical behavior in organizational context has been most frequently described in terms of ethical standards of senior leaders (CEOs) and the culture to which they substantially contribute (DeGeorge, 1986).

We define leadership as the art of persuading a follower to want to do the things, activities, that the leader sets as goals. The role of leaders is therefore in the process of directing the individual's behaviour towards a desired goal. Leaders vary depending on the individual leadership style that stems from personality characteristics. Some leaders, particularly charismatic and transformational, have personal power through which they engage employees, whereas other exert the positional, legitimate power. Leaders are characterized by different values, attitudes, beliefs, conduct, habits and practices and that is to a certain extent dependent upon the organizational, professional or institutional culture.

Leadership signifies a relation between a leader and his followers within a situational and organizational context. According to insights and research by Rost leadership is defined as a power- and value-laden relationship between leaders and followers/constituents who intend real changes that reflect their mutual purposes and goals (Rost, 1993). Leadership in the context of normative organizational ethics would be defined with regard to how individuals should or ought to behave in an organization. This includes speculations about criteria that define ethical decisions and personality characteristics. Ethical leadership is crucial and vital in providing direction that enables the organization to fulfil its mission and vision and achieve declared goals (Kanungo \& Mendonca, 1996). Ethical leadership is regarded as a key factor in the management of an organization's reputation in the external environment and in comparison with competitors (Blanchard \& Peale, 1996; Kanungo \& Mendonca, 1996). An organization's moral health depends upon the standards and the example of the chief executive (Kelly, 1990). According to Hitt senior leadership has two key responsibilities: 1) to ensure that ethical decisions were made; 2) to develop an organizational climate in which ethical follower conduct was fostered (Hitt, 1990).

Ethical leadership is a construct that appears to be ambiguous and includes various diverse elements (G. Yukl, 2006). Instead of perceiving ethical leadership as preventing people from doing the wrong thing, authors propose that we need to view it as enabling people to do the right thing (Freeman \& Stewart, 2006). An ethical leader is a person living up to principles of conduct that are crucial for him. To be an ethical leader one needs to adhere to a more universal standard of moral behaviour (Thomas, 2001). Leading ethically is believed to be a process of inquiry - asking questions about what is right and what is wrong - and a mode of conduct - setting the example for followers and others about the rightness or wrongness of particular actions (Guy, 1990).

Ethical leadership can be viewed in terms of healing and energizing powers of love, recognizing that leadership is a reciprocal relation with followers. Leader's mission is to serve and support and his passion for leading comes from compassion (Kouzes \& Posner, 1992). That ethical leadership is starting to receive attention is even shown in an effort to boil ethical leadership down to love (Kouzes \& Posner, 1992). 
Based on an extensive review of literature Brown and colleagues formed the following definition: ethical leadership is defined as "the demonstration of normatively appropriate conduct through personal actions and interpersonal relationships, and the promotion of such conduct to followers through two-way communication, reinforcement and decision-making" (Brown et al., 2005, p. 120). This definition proposes that 1) ethical leaders' conduct serves as role-modelling behaviour for followers as their behaviour is accepted as appropriate; 2) ethical leaders communicate and justify their actions to followers (i.e. they make ethics salient in their social environment) (Bass \& Steidlmeier, 1999); 3) ethical leaders want to continually behave according to ethics, therefore they set ethical standards in the company and reward ethical conduct (Minkes et al., 1999) on the part of employees as well as punish unethical behaviour; 4) ethical leaders incorporate ethical dimension in the decision-making process, consider the ethical consequences of their decisions and above all try to make fair choices. The above definition places ethical leadership among the positive forms of leadership and focuses on leader behaviour and thereby disentangles personal characteristics, attitudes from the actual behaviour.

Ciulla proposes that an ethical leader is an effective leader (Ciulla, 1995). In practice though, we more frequently find effective and unethical or ineffective and ethical leaders. Ciulla argues that at times just the fact that one is regarded as ethical and trustworthy makes him effective, whereas sometimes being highly effective makes one ethical. There is also the problem of criterion of good leadership as such; sometimes being ethical seems reasonable and appropriate in the short run and it is not right in the long run. A particular behaviour might be correct from the intra-organizational perspective but is incorrect in society. Sometimes it occurs that leaders have moral intentions, but due to their incompetence create unethical outcomes (Ciulla, 2005).

Enderle proposes two goals of (managerial) ethical leadership, the first is to explicitly state the ethical dimension that exists in each and every managerial decision, whereas the second is to formulate and justify ethical principles (that are an essential aid for responsible leadership) which cannot substitute for personal responsibility in decision-making (Enderle, 1987). Being ethical involves "doing more than fulfilling moral minima and moral courage" (Murphy \& Enderle, 1995, str. 126). A person with an ethical mind, according to Howard Gardner, a professor at Harvard Graduate School of Education asks himself the following question: "What kind of a person, worker and citizen do I want to be? If all workers in my profession adopted the mind-set I have and did what I do, what would the world be like? (Kannair, 2007).

\section{LEADER - FOLLOWER RELATIONSHIP AND (UN)ETHICAL BEHAVIOR}

It's not enough to espouse high standards. To live up to them - and help others do the same - requires an ethical cast of mind that lets you practice your principles consistently (Kannair, 2007, p. 51).

Being ethical is about playing fair, thinking about welfare of others and thinking about consequences of one's actions. However, even if one grows up with a strong sense for good or bad, the bad behaviour of others can undermine his ethical sense as well. Ethical leaders think about long-term consequences, drawbacks and benefits of their decisions. For the sake of being true to their own values and beliefs, they are prepared to compete in a different battle on the market, where the imperative is: Do what is right.

Leaders serve as role models for their followers and demonstrate the behavioural boundaries set within an organization. The appropriate and desired behaviour is enhanced through culture and socialization process of the newcomers. Employees learn about values from watching leaders in action. The more the leader "walks the talk", by translating internalized values into action, the higher level of trust and respect he generates from followers. When leaders are prepared to make personal sacrifices for followers or the company in general for the sake of acting in accordance with their values, the employees are more willing to do the same.

As managers take the issue of ethical responsibility seriously, they immediately become more sensitive to followers' needs and problems of those who will be affected, thereby becoming more able to discern intuitively the emerging conflicts (Enderle, 1987). Good leaders are designated by an enhanced capacity to feel morally obligated to a wide range of followers and this is not a skill, but knowledge and world perspective (Ciulla, 2005). Ethical leadership brings favourable consequences for followers and organization that are reflected in perceived leaders' effectiveness, followers' job satisfaction, increased dedication and problem reporting (Brown et al., 2005). 
With regard to leader-follower relationship ethics should be a process rather than a one-time sporadic event. To be able to influence followers' ethical behaviour, leaders must communicate ethical standards and continually evaluate real examples (Brown, 2007). This means that solely writing a code of ethics is not a sufficient step towards implementation of ethical behaviour in organizations. Ethics should be ingrained in each and every pore of organizational life. Ethical leaders are perceived as people who do not tolerate ethical lapses, they rather discipline people for wrong behaviour (L. K. Trevino, Brown, \& Hartman, 2003). Trevino and her colleagues interviewed senior executives and ethics officers in America and found that to be perceived as an ethical leader one has to be honest, trustworthy, show credibility and demonstrate integrity, needs to walk the ethical talk is courageous and strong (L. K. Trevino et al., 2003).

Previous surveys suggested that traits such as integrity, credibility, honesty are also associated with a perception of an effective leader (Bass \& Stogdill, 1990). Based on a philosophical foundation Marcic outlines five virtues that are crucial for a leader-follower relationship: trustworthiness, unity (seeking unanimity in strategic decisions), respect and dignity (as a basis for true empowerment), justice, service (being servant to employees and customers) and humility (Marcic, 1997).

Rubin, Dierdorff and Brown examined the consequences of ethical leadership in form of promotion on a sample of ninety-six managers and found, that ethical leaders were increasingly likely to be rated (by their superior) as exhibiting potential for senior leadership positions. Surprisingly though, leaders who demonstrated increased ethical leadership were no more likely to be viewed as promotable in the short-run in comparison with those who displayed less ethical behavior (Rubin, Dierdorff, \& Brown, 2010).

The possibilities to behave unethically in an organization are limitless and unfortunately, this potential is too often realized. Why do ethics matter? Ethical companies can recruit candidates more efficiently, choosing those recruits that will fit the existing organizational values. Namely, people usually want to work for a high-quality organization with excellent reputation. Consumers want to deal with a reputable company and business partners search for renowned companies as only with such companies it is possible to foster trust based relationships (Bazerman, 2008). Why do people (leaders and followers) in organizations not behave as ethically as they should? According to young managers because they are pressured to comply with four powerful organizational commandments: performance is what counts in the end; by all means show that you are loyal and a team-player; do not break the law; do not over-invest in ethical behaviour. These rules are hardly sufficient to create and ethical organization. What is even more interesting is that only a minority of young managers believes that ethics pays in terms of career advancement (J. L. Badaracco \& Webb, 1995).

Gentile interviewed managers in their early career trying to find out what impedes people to stay silent when encountered with an ethical issue. She found there to be four classic rationalizations for doing nothing. The first is the excuse that" it's standard practice", everyone in the companies does this on a daily basis. The second is that and individual attempts to find an apology in the phrase "it's not a big deal". This is a common argument we can hear among co-workers particularly when they are under time pressure. Third statement is "it's not my responsibility". One just might be tempted to speak his mind, but as he does not have the authority (particularly if he is a younger employee) and it is not his responsibility, he remains quiet. The last statement refers to "I want to be loyal". On many occasions people feel there is a conflict between doing what is right and being loyal to the leader and co-workers, which can be an ethical dilemma as well (Gentile, 2010). Badaracco and Webb performed a series of in-depth interviews of recent Harvard MBA graduates to find out how young managers perceive, define and resolve ethical issues. Analysis revealed that managers received explicit instructions from above to do things that they felt were unethical. They even felt strong organizational pressure. Next, they felt that codes of conducts, ethics programmes provided little help and even believed that the respective company was out-of-touch on ethical issues (either due to busyness or deliberate avoidance of responsibility). Therefore, young managers used personal values and reflection to resolve the ethical dilemmas and did not rely on corporate credo (J. L. Badaracco \& Webb, 1995).

For majority of employees, speaking up about an ethical issue is more difficult than disagreeing in starting a conflict. That is why it is the leader's job to foster an ethical climate that enables sincere and open communication and culture that promotes and rewards ethical behaviour. Of the values that make up an organization's culture, those referring to ethics are the most important. Leaders should shape ethical values primarily through ethical (value- 
based) leadership both through their personal behaviour as well as organizational policies and processes. Ethics committees, chief ethics officers, ethical training programs, disclosure mechanisms and code of ethics can support employees in raising concerns about ethical practices as long as the leaders at the top set the example. It is important that the leader shows and encourages employees to speak up, because if employees do not perceive that they can voice their values, they will not even bother trying.

Gentile suggests the following in order to confront the problem of not reporting unethical behaviour: Treat the conflict as a business matter; recognize that ethical dilemmas are a part of your job; be yourself, act authentically; challenge the rationalizations (challenge the so-called standard practices) turn newbie (new-comer) status into an asset; expose faulty thinking; make long-term risks more specific; present alternative solutions to unethical actions (Gentile, 2010).

\section{PERSONALITY CHARACTERISTICS OF ETHICAL LEADERS}

\section{Traits}

Leader's character influences his ethical performance, but solely poor character does not fully explain ethical lapses in corporations. However, it is true, that a strong character plays an important role in effective selfleadership and in the process of leading others. Leaders therefore must rely on their inner voice, inner compass that points them in the ethical direction (Brown, 2007). In his book, Covey addresses the issue of ethical leadership with the term "Character ethics", that he understands not as of individual character, but of "principles that govern human effectiveness" being self-validating natural laws (Covey, 2004, p. 32). The mode in which ethical standards and consequently conduct are neglected or applied is a function of individual characteristics. Covey's view on effective leadership with a strong ethical component is described in the following sentence: "To value oneself and, at the same time, subordinate oneself to higher purposes and principles is the paradoxical essence of the highest humanity and the foundation of effective leadership (Covey, 2004, p. 19).

Jones asserts that ethical conduct is a result of one's personal dispositions, his character and not a result of learning experience. He asserts that ethical leader is an ascetic construct, whereby ascetic describes a self-controlled, purposeful person who is mindful with regard to consequences (Jones, 1995). He continues that "the ascetic person lives from within. He or she is a person who regards life as the occasion for commitment to ends higher than one's own immediate happiness and well-being (Jones, 1995, p. 869). He believes that being ethical is a personal quality tied to characteristic habits, therefore training programs emphasizing self-evident moral principles might not be as effective as we wish. It is assumed that consistently ethical behaviour is the result of the process of socialization infinitely more thoroughly than any organizational training program.

The criteria relevant for judging ethical behaviour of a leader include individual values, conscious intentions, freedom of choice, stage of moral development, types of influence used, and use of ethical as well as unethical behaviour (G. Yukl, 2006). Some of the characteristic behaviours of ethical and unethical leaders are shown in the table below.

Table 1: Ethical and unethical leadership

\begin{tabular}{|l|l|}
\hline \multicolumn{2}{|c|}{ The Ethical Leader } \\
\hline Is humble & \multicolumn{1}{c|}{ The Unethical Leader } \\
\hline Is concerned for the greater good & Is arrogant and self-serving \\
\hline Is honest and straightforward & Excessively promotes self-interest \\
\hline Fulfils commitments & Practices deception \\
\hline Strives for fairness & Breaches agreements \\
\hline Takes responsibility & Deals unfairly \\
\hline Shows respect for each individual & Shifts blame to others \\
\hline Encourages and develops others & Diminishes others' dignity \\
\hline Serves others & Neglects follower development \\
\hline Shows courage to stand up for what is right & Withholds help and support \\
\hline
\end{tabular}

Source: (Zanderer, 1992) 
The traits that CEOs most often attribute to ethical leaders are honesty, trustworthiness and integrity. Trust is associated with credibility, consistency and predictability in relationships, honesty is the crucial element needed in a trust-based relationship. Ethical leaders treat people right, have a high level of moral development and play fair (L.K. Trevino, Hartman, \& Brown, 2000). The leader who is honest with and about himself and with others inspires trust that encourages followers to take responsibility. For more than a decade, Kouzes and Posner have been asking employees around the world what they most value or want from a leader and what would it take for them to follow him willingly. And without exception honesty (integrity, trustworthiness) is the first on the list (Kouzes \& Posner, 1992). And how do employees know that leaders are (dis)honest? They observe the behaviour and the consistency of behaviour in similar conditions. If a leader constantly changes his behaviour, followers perceive him as unpredictable, unreliable, and therefore unworthy of trusting. Another thing that undermines trust is if a leader espouses one set of values (the way he should behave) and actively promotes them, whereas personally practices another set.

\section{Values}

Ethical values in an organizational setting are emphasized and strengthened primarily through values-based leadership, that can be defined as a relationship between leaders and co-workers, based on shared, internalized values, that are acted upon by the leader (Daft, 2007). Values are general principles that guide action. Values are not actions, they are codes which underlie the sanctions or punishments for some choices of behavior and rewards for other. Throughout history values have sparkled interest of many researchers in various sciences. With staggering growth of companies, management researchers became interested in this topic as well. They came to realization that values have a profound effect on a leader's performance. According to Dolan et al (2006), ethical moral values refer to forms of conduct that one has to live by in order to reach desired outcomes in the form of final values. The word "moral" derives from the Latin expression "mores" which means customs. In the table below are examples of different types of values that can be attributed to leaders.

Table 2: Examples of final (personal and ethical-social) and instrumental values (ethical-moral and values of competition)

\begin{tabular}{|l|l|}
\hline $\begin{array}{l}\text { Personal values: } \\
\text { What are the most important things in your life? }\end{array}$ & $\begin{array}{l}\text { Happiness, health, salvation, family, personal success, recognition, status, } \\
\text { material goods, friendship, success at work, love. }\end{array}$ \\
\hline $\begin{array}{l}\text { Ethical-social values: } \\
\text { What do you want to do for the world? }\end{array}$ & Peace, planet ecology, social justice \\
\hline $\begin{array}{l}\text { Ethical-moral values: } \\
\text { How do you think you should behave towards } \\
\text { people that surround you? }\end{array}$ & $\begin{array}{l}\text { Honesty, sincerity, responsibility, loyalty, solidarity, mutual confidence, } \\
\text { respect for human rights }\end{array}$ \\
\hline $\begin{array}{l}\text { Values of competition: } \\
\text { What do you believe is necessary to compete in life }\end{array}$ & $\begin{array}{l}\text { Money, imagination, logic, beauty, intelligence, positive thinking, } \\
\text { flexibility, }\end{array}$ \\
\hline
\end{tabular}
Source: (Dolan, Garcia, \& Richley, 2006, p. 33)

Business ethicist, Professor Baradarcco believes that over the course of his career a leader needs to embrace a more complex code of ethical behaviour compared to the one learned in childhood and adolescence. He contends that real morality is not binary it rather emerges in many shades of gray. That is the reason why leaders need ethical codes that are as varied, complex and indeed subtle as the situation they face. Consequently, leaders need to embrace a wider set of human values and constantly evaluate their basic values (J. J. L. Badaracco, 2006).

On the basis of virtue (value) theory five values are crucial for ethical leaders (Blanchard \& Peale, 1996):

- $\quad$ Pride. Lacking self-esteem an ethical leader will hardly receive esteem and respect from followers. Ethical leaders demonstrate healthy pride, not vanity, as the dividing line between them is thin due to strong egotistic tendency in human beings. Ethical leaders recognize that inordinate self-love is a vice not virtue.

- $\quad$ Patience. In the process of implementing strategies that enable an organization to reach its goals, a leader is faced with obstacles from internal and external environment, reluctance and lack of commitment from followers. As it takes time to overcome barriers patience is of utmost importance. 
- $\quad$ Prudence. Prudence is a virtue that refers to exercising sound judgement in practical affairs. It is considered as the measure of moral virtues as it provides a model of ethically good actions. A leader in the habit of exercising prudence and fortitude is not inclined to resort to unethical practices even in times when things do not go as planned.

- $\quad$ Persistence. It refers to leader's striving for goals and his continuing quest to take all the necessary steps to achieve them, even if they involve sacrifice and personal risk. Persistence lies in trying to overcome the "practice" of justifying unethical conducts when one feels overwhelmed by mounting pressures, because of a sense of duty to others.

- $\quad$ Perspective. It is understood as the capacity to perceive what is truly important in any given situation.

Twenty-one effective and twenty-one less effective top executives of non-profit organizations participated in a study of ethical reasoning. Researchers showed that executives preferring principled ethical reasoning are more likely to be effective. Namely, when confronted with ethical dilemmas, effective executives engage in significantly more complex cognitive reasoning about these issues than less effective executives. The effective executives base evaluations of moral decisions on calculated rights, values and own principles, rather than on public opinion. They are also more likely to make a decision that may be unpopular in society but is right from the ethical stance. Consequently they are willing to accept the ensuing conflicts that may result from these decisions. (Jurkiewicz \& Massey Jr, 1998). Less effective executives do the right thing within the context of "doing one's duty in the society", display obedience to authority, are more concerned with how their decisions might be viewed by others (in and outside the organization). (Jurkiewicz \& Massey Jr, 1998).

\section{Integrity}

Today one of the traits most cited as required in order to exercise effective leadership is integrity. In fact, a crucial point that distinguishes a Fortune 500 organization from its competitors is the integrity of profit making and other resource allocation practice by managers and owners (Blanchard, O'Connor, O'Connor, \& Ballard, 1997). Or as Minkes and colleagues put it: "Leaders without integrity are only putting on an act; once values are agreed upon and in place, the CEO should put them into practice." (Minkes et al., 1999, p. 330).

The leaders that demonstrate integrity are honest with themselves and others, learn from mistakes and are constantly in the process of self-improvement. They lead by example and expect as much of others as they do of themselves. They take responsibility to be judgemental about important decisions and strive to balance competing interests when in the process of reaching crucial organizational goals (Hoenig, 2000). An integrity-based approach to managing ethically combines obedience of the law with an emphasis on managerial responsibility for ethical behaviour. Integrity strategies define companies' guiding values, aspirations and patterns of thought and conduct. Once these are implemented and integrated into daily organizational activities, such strategies help prevent damaging ethical lapses (Paine, 1994). Raytheon's CEO, Dan Burhnam shares his view on integrity within ethical leaders: "The CEO must be the chief ethics offices of the firm. Her or she cannot delegate integrity...The CEO must make everyone understand that the organization's future is dependent on its reputations. The organization has to be personal, human and individual...If unethical behaviour is uncovered, it's important to act swiftly and decisively (Fulmer, 2004, p. 310).

\section{THE LEADER'S ROLE IN FOSTERING ETHICAL BEHAVIOUR IN ORGANIZATIONS}

Leaders are the primary influence on ethical conduct in an organization (Hitt, 1990; Jansen \& Von Glinow, 1985 ) and are responsible for the norms and codes of conduct that guide employees' behaviour (Bennis \& Nanus, 1985; Cyert, 1990). For Enderle there are three ethical tasks a leader should normatively involve in: perceiving, interpreting and creating reality; showing responsibility for the effects of one's decisions on the human beings concerned; being responsible for the implementation of organizational goals (Enderle, 1987). Thomas believes that the motivation to be ethical comes from one's decision to live life in a certain way. If people opt to follow your leadership, they tend to follow that same conduct that you exhibit (Thomas, 2001). The people namely watch the walk, they usually do not listen to the talk. In real life one's behaviour depends both on the situation one finds himself in, as well as on standards of behaviour. Rost contends that the majority of people do not use particular ethical frameworks to judge morality. Instead, they use personal and cultural values, religious beliefs, ideology, 
organizational mores, family upbringing practices, own behavioural experience and intuition (Rost, 1995). Gardner even believes that it is more difficult for businesspeople to adhere to an ethical mind than it is for other professionals, because in business one does not need a licence to practice. It is relatively easy to wander off the correct path, as professional standards are more a vocational option than part of the territory (Kannair, 2007). In business world, an organization can voluntarily take on corporate social responsibility. However, there are no penalties if it chooses not to.

Gellerman asserts that management/leadership in an organization holds the responsibility for developing and sustaining conditions in which people are likely to behave themselves, and for minimizing conditions in which they may be tempted to misbehave (Gellerman, 1989). It seems that setting the tone at the top is a crucial but not sufficient condition. Leadership must actively pursue that its quest for greater efficiency and effectiveness does not inadvertently lead people into more temptation than they can resist. Leaders who fail to provide ethical leadership and develop procedures that facilitate ethical conduct share responsibility with those who conceive, execute and benefit from corporate misdeeds (Paine, 1994). In the table below, the criteria for evaluation of ethical and unethical leadership are presented.

Table 3: Criteria for evaluation of ethical leadership

\begin{tabular}{|l|l|l|}
\hline \multicolumn{1}{|c|}{ Criterion } & \multicolumn{1}{|c|}{ Ethical Leadership } \\
\hline Use of leader power and influence & Serves followers and the organization & $\begin{array}{l}\text { Satisfies personal needs and career } \\
\text { objectives }\end{array}$ \\
\hline $\begin{array}{l}\text { Handling diverse interests of multiple } \\
\text { stakeholders }\end{array}$ & Attempts to balance and integrate them & $\begin{array}{l}\text { Favours coalition partners who offer the } \\
\text { most benefits }\end{array}$ \\
\hline $\begin{array}{l}\text { Development of a vision for the } \\
\text { organization }\end{array}$ & $\begin{array}{l}\text { Develops a vision based on follower } \\
\text { input about their needs, values and ideas }\end{array}$ & $\begin{array}{l}\text { Attempts to sell a personal vision as the } \\
\text { only way for the organization to succeed }\end{array}$ \\
\hline Integrity of leader behaviour & Acts consistent with espoused values & $\begin{array}{l}\text { Does what is expedient to attain personal } \\
\text { objectives }\end{array}$ \\
\hline $\begin{array}{l}\text { Risk taking in leader decisions and } \\
\text { actions }\end{array}$ & $\begin{array}{l}\text { Is willing to take personal risks and } \\
\text { make necessary decisions }\end{array}$ & $\begin{array}{l}\text { Avoids necessary decisions or actions } \\
\text { that involve personal risk to the leader }\end{array}$ \\
\hline $\begin{array}{l}\text { Communication of relevant } \\
\text { information operations }\end{array}$ & $\begin{array}{l}\text { Makes a complete and timely disclosure } \\
\text { of information about events, problems } \\
\text { and actions }\end{array}$ & $\begin{array}{l}\text { Uses deception and distortion to bias } \\
\text { follower perceptions about problems and } \\
\text { progress }\end{array}$ \\
\hline $\begin{array}{l}\text { Response to criticism and dissent by } \\
\text { followers }\end{array}$ & $\begin{array}{l}\text { Encourages critical evaluation to find } \\
\text { better solutions }\end{array}$ & $\begin{array}{l}\text { Discourages and suppresses criticism or } \\
\text { dissent }\end{array}$ \\
\hline $\begin{array}{l}\text { Development of follower skills and self- } \\
\text { confidence }\end{array}$ & $\begin{array}{l}\text { Uses coaching, mentoring and training to } \\
\text { develop followers }\end{array}$ & $\begin{array}{l}\text { Deemphasizes development to keep } \\
\text { followers weak and dependent on the } \\
\text { leader }\end{array}$ \\
\hline
\end{tabular}

Source: (G. A. Yukl \& Yukl, 2002, p. 422)

In their essay Kouzes and Posner offer practical suggestions for being an ethical leader, explaining that this emanates not so much from the head as it does from the heart. Based on numerous interviews they conclude that love constitutes the soul of ethical leadership. They also observe that when working at his personal best - that means leading with love, with a feeling of warm personal attachment - leaders are transforming their followers into leaders. Love in an organizational sense creates the desire to see others grow and become better (Kouzes \& Posner, 1992). Another "recipe" to keep oneself on the path of ethics is to undergo a "positive periodic inoculations", which happen when one meets individuals or experiences situations that force him to examine what he is doing or is trying to do to set a good example for others (Kannair, 2007).

Basic rules of conduct that ethical leaders should follow in order to be considered true leaders are outlined as follows (Freeman, Martin, Parmar, Cording, \& Werhane, 2006):

- $\quad$ Leader principle: a leader is foremost a member of the company and its spokesman, therefore his deeds must serve the purpose and benefits of the corporation

- Constituents principle: leaders respect their co-workers and perceive them as people who share common purpose. Their individuality and freedom is accepted within the borders of ethical behaviour 
- $\quad$ Outcome principle: a leader connects values to stakeholder support as well as societal legitimacy. Company mission, vision, values and goals (strategy and tactics) are outlined within an understanding of ethical ideals

- Processes/skills principle: the leader is open to different opinions and ideas, views and creates an atmosphere of dynamic and fruitful communication

- Situation/context principle: moral judgements are used to make ethical decisions and when crossing the boundaries of different ideas. The ethical leader knows the limits of the values and ethical principles they live.

- $\quad$ Ethics principle: a leader understands leadership and ethics as an integrated process and frames actions and purposes in ethical terms.

Murphy and Enderle studied examples of ethical behaviour of four retired CEOs who have written or spoken about ethics, using a narrative approach in order to understand ethical behaviour and learn from it. After studying their behaviour, interviews and writings about business and ethics they summarized the following common themes. All four leaders demonstrate a strong commitment to perceive and interpret reality within the context of honesty and openness. The latter traits are particularly sought after in times of crisis when a leaders needs to maintain. Next, leaders are able to create reality by continually reaffirming the ideals and beliefs of their respective organizations. They are also particularly concerned for how their decisions affect other people. Namely, they realize that managerial decisions have an enormous impact on professional and private life of stakeholders (starting with employees). From the perspective of personality, leaders possess an exceptionally strong motivation and are emotionally strong, courageous, fair in treating all employees, just and advocate temperance. Finally, leaders hold strong religious values, as their moral commitment seems to be rooted in religious conviction that brings a sense of unconditional obligation to others (Murphy \& Enderle, 1995).

The determinants of highly ethical organization according to Pastin include: 1) individuals who recognize and accept personal responsibility for the actions of the organization; 2) a profound devotion to fairness with an emphasis on the other person; 3) being comfortable with interacting with external groups; 4) tying all activities in with an overall purpose (Pastin, 1986). CEOs have an important role to play in implementing an organizational culture which Hitt refers to as clarifying values (Hitt, 1990).

\section{CONCLUDING REMARKS}

Can a company be successful and competitive on the market and at the same time ethical? Akers believes that market success and ethical conduct go hand in hand: "Ethics and competitiveness are inseparable. We compete as a society. No society anywhere will compete very long or successfully with people stabbing each other in the back; with people trying to steal from each other; with everything requiring notarized confirmation because you can't trust the other fellow; with every little squabble ending in litigation; and with government writing reams of regulatory legislation, trying business hand and foot to keep it honest"(Akers, 1989, p. 69). It pays to be ethical, is one of the key findings in a study by U.K. Institute of Business Ethics. In a sample of 350 large U.K. "ethical" companies (where performance was measured between 1997 and 2001) there was strong indicative evidence that companies with codes of business ethics produced an above-average performance when measured against a similar group without codes (Fulmer, 2004).

\section{AUTOR INFORMATION}

Katarina Katja Mihelič is a teaching assistant at the Department of Management and Organization at Faculty of Economics, University of Ljubljana (Slovenia). She received her Msc in business administration and organization. Her current research fields are work ethics and organizational culture. She attended several international conferences, where she presented papers in her research area.

Bogdan Lipičnik is an associate professor for organizational behavior and human resource management at the Faculty of Economics, University of Ljubljana. He has attended international conferences, published several papers in journals and worked as a consultant for many companies in Slovenia. His research focuses on organizational climate, managerial styles, problem-solving styles and effective methods of job evaluation. 
Metka Tekavčič is a professor at the Department of Management and Organization at the Faculty of Economics, University of Ljubljana. She is the Head of the Institute of Management and Organisation. Her research interests are in cost management and performance measurement. She attended many international conferences, where she presented papers in her research area and published several articles in European and US journals. She is a member of editorial boards in several journals from her research field.

\section{REFERENCES}

1. Akers, J. (1989). “Ethics and competitiveness putting first things first". Sloan Management Review, 30(2), 69-71.

2. Badaracco, J. J. L. (2006). Leadership in Literature, Harvard Business Review (Vol. 84, pp. 47-55): Harvard Business School Publication Corp.

3. Badaracco, J. L., \& Webb, A. (1995). Business ethics: A view from the trenches. California Management Review, 37, 8-8.

4. Bass, B. M., \& Steidlmeier, P. (1999). Ethics, character, and authentic transformational leadership behavior. The Leadership Quarterly, 10(2), 181-217.

5. Bass, B. M., \& Stogdill, R. M. (1990). Bass \& Stogdill's handbook of leadership: Theory, research, and managerial applications: Free Pr.

6. Bazerman, M. H. (2008). Evaluating Your Business Ethics: A Harvard professor explains why good people do unethical things, Gallup Management Journal Online (pp. 1-5): Gallup Poll News Service.

7. Bennis, W., \& Nanus, B. (1985). Leadership: The strategies for taking charge: New York: Harper \& Row.

8. Blanchard, K. H., O'Connor, M., O'Connor, M. J., \& Ballard, J. (1997). Managing by values: BerrettKoehler Pub.

9. $\quad$ Blanchard, K. H., \& Peale, N. V. (1996). The power of ethical management: Ballantine Books.

10. Brown, M. E. (2007). Misconceptions of Ethical Leadership::: How to Avoid Potential Pitfalls. Organizational Dynamics, 36(2), 140-155.

11. Brown, M. E., \& Trevino, L. K. (2006). Ethical leadership: A review and future directions. The Leadership Quarterly, 17(6), 595-616.

12. Brown, M. E., Trevino, L. K., \& Harrison, D. A. (2005). Ethical leadership: A social learning perspective for construct development and testing. Organizational Behavior and Human Decision Processes, 97(2), $117-134$.

13. Ciulla, J. B. (1995). Leadership ethics: Mapping the territory. Business Ethics Quarterly, 5(1), 5-28.

14. Ciulla, J. B. (2005). Integrating leadership with ethics: is good leadership contrary to human nature? In P. J. Doh \& S. A. Stumpf (Eds.), Handbook on responsible leadership and governance in global business (pp. 159-179). Cheltenham UK: Edward Elgar Publishing Limited.

15. Covey, S. R. (2004). Seven habits of highly effective people: Free Pr.

16. Cyert, R. M. (1990). Defining leadership and explicating the process. Nonprofit Management \& Leadership, 1(1), 29-38.

17. Daft, R. L. (2007). The leadership experience: South-Western Pub.

18. DeGeorge, R. T. (1986). Business ethics. New York.

19. Dolan, S. L., Garcia, S., \& Richley, B. (2006). Managing by values; A corporate guide to living, being alive and making a living in the 21st century. New York: Palgrave Macmillian.

20. Enderle, G. (1987). Some perspectives of managerial ethical leadership. Journal of Business Ethics, 6(8), 657-663.

21. Freeman, R. E., Martin, K., Parmar, B., Cording, M., \& Werhane, P. H. (2006). Leading through values and ethical principles. In R. J. Burke \& C. L. Cooper (Eds.), Inspiring Leaders, Routledge Publishing. Oxford, $U K$.

22. Freeman, R. E., \& Stewart, L. (2006). Developing ethical leadership. Bridge Paperso. Document Number)

23. Fulmer, R. M. (2004). The challenge of ethical leadership. Organizational Dynamics, 33(3), 307-317.

24. Fulmer, R. M. (2005). What leaders and their organizations can do to develop ethical leaders. In P. J. Doh \& S. A. Stumpf (Eds.), Handbook on responsible leadership and governance in global business (pp. 4253). Cheltenham, UK: Edward Elgar Publishing Limited.

25. Gellerman, S. W. (1989). Managing ethics from the top down. Sloan Management Review, 30(2), 73-79.

26. Gentile, M. C. (2010). Keeping Your Colleagues Honest. Harvard Business Review, 88(3), 114-117. 
27. Guy, M. E. (1990). Ethical decision making in everyday work situations: Greenwood Publishing Group.

28. Hitt, W. D. (1990). Ethics and leadership: Putting theory into practice. Columbus: Battelle Press.

29. Hoenig, C. (2000). Brave hearts. CIO, November, 1

30. Jansen, E., \& Von Glinow, M. A. (1985). Ethical ambivalence and organizational reward systems. Academy of Management Review, 814-822.

31. Jones, H. B. (1995). The ethical leader: An ascetic construct. Journal of Business Ethics, 14(10), 867-874.

32. Jurkiewicz, C. L., \& Massey Jr, T. K. (1998). The Influence of Ethical Reasoning on Leader Effectiveness. Nonprofit Management \& Leadership, 9(2), 173-187.

33. Kannair, J. (2007). The Ethical Mind. Harvard Business Review, 85(3), 51-56.

34. Kanungo, R. N., \& Mendonca, M. (1996). Ethical dimensions of leadership: Sage Publications, Inc.

35. Kelly, D. J. (1990). Ethics: The Tone at the Top'. Management Accounting, 70(10), 18-19.

36. Kouzes, J. M., \& Posner, B. Z. (1992). Ethical leaders: an essay about being in love. Journal of Business Ethics, 11(5), 479-484.

37. Marcic, D. (1997). Managing with the wisdom of love: Uncovering virtue in people and organizations: Jossey-Bass.

38. Minkes, A. L., Small, M. W., \& Chatterjee, S. R. (1999). Leadership and business ethics: Does it matter? Implications for management. Journal of Business Ethics, 20(4), 327-335.

39. Murphy, P. E., \& Enderle, G. (1995). Managerial ethical leadership: examples do matter. Business Ethics Quarterly, 5(1), 117-128.

40. Paine, L. S. (1994). Managing for organizational integrity. Harvard Business Review, 72, 106-106.

41. Pastin, M. (1986). The hard problems of management: Getting the Ethics Edge. Los Angeles: Jossey-Bass Publ.

42. Rost, J. C. (1993). Leadership for the twenty-first century: Praeger Publishers.

43. Rost, J. C. (1995). Leadership: A discussion about ethics. Business Ethics Quarterly, 5(1), $129-142$.

44. Rubin, R. S., Dierdorff, E. C., \& Brown, M. E. (2010). Do Ethical Leaders Get Ahead? Exploring Ethical Leadership and Promotability. Business Ethics Quarterly, 20(2), 215-236.

45. Sims, R. R. (1992). The challenge of ethical behavior in organizations. Journal of Business Ethics, 11(7), 505-513.

46. Thomas, C. (2001). The Ethical Leader, Executive Excellence (Vol. 18, pp. 15): Executive Excellence Publishing.

47. Trevino, L. K. (1986). Ethical decision making in organizations: A person-situation interactionist model. Academy of Management Review, 11(3), 601-617.

48. Trevino, L. K., Brown, M., \& Hartman, L. P. (2003). A qualitative investigation of perceived executive ethical leadership: Perceptions from inside and outside the executive suite. Human Relations, 56(1), 5.

49. Trevino, L. K., \& Brown, M. E. (2005). Managing to be ethical: Debunking five business ethics myths. Strategic human resource management: theory and practice.

50. Trevino, L. K., Hartman, L. P., \& Brown, M. E. (2000). Moral person and moral manager: How executives develop a reputation for ethical leadership. California Management Review, 42(4), 128-142.

51. Yukl, G. (2006). Leadership in organizations, 6th edition. New Jersey: Pearson Prentice Hall Upper Saddle River, NJ.

52. Yukl, G. A., \& Yukl, G. (2002). Leadership in organizations: Prentice Hall Upper Saddle River, NJ.

53. Zanderer, D. G. (1992). Integrity: An essential Executive quality. Business Forum, Fall, 12-16 
NOTES 